\title{
Evaluating sediment transport capacity relationships for use in ephemeral gully erosion models
}

\author{
EDDY J. LANGENDOEN, ROBERT R. WELLS, MICK E. URSIC, \\ DALMO A. N. VIEIRA \& SETH M. DABNEY \\ US Department of Agriculture, Agricultural Research Service, National Sedimentation Laboratory, PO Box 1157, \\ Oxford, MS 38655, USA \\ eddy.langendoen@ars.usda.gov
}

\begin{abstract}
On cropland, ephemeral gully erosion in the USA may contribute up to $40 \%$ of the sediment delivered to the edge of the field. Well-tested, physically- and process-based tools for field and watershed scale prediction of gully erosion are lacking due to the fact that the complex nature of migrating headcuts is poorly understood. Understanding sediment transport capacity downstream of migrating headcuts is essential, as sediment deposition often leads to temporary storage that controls downstream water elevation, which in turn affects the rate of headcut migration. Current process-based gully erosion prediction technology used by the Agricultural Research Service (ARS) is based on characterizing the headcut migration rate, which requires the deposition depth as input to the model. Alternatively, the deposition depth can be calculated if downstream sediment transport capacity can be predicted. Data collected at the ARSNational Sedimentation Laboratory were used to test existing sediment transport relationships for the five sediment size classes (clay, silt, sand, small aggregates, large aggregates) typically used in ARS soil erosion models. The results show that the transport rate can be satisfactorily predicted for sand and large aggregate size fractions using common transport relationships based on unit stream power theory. The fractional content of the sand and large aggregate size classes can be computed using standard relationships, which are based on soil texture, previously developed by ARS. The transport of clays, silts and small aggregates is detachment limited and must therefore be computed using improved soil detachment relationships for ephemeral gullies.
\end{abstract}

Key words erosion; sediment; gully; transport capacity

\section{INTRODUCTION}

Soil loss from cultivated lands has been typically associated with sheet and rill erosion processes and previous research has focused on controlling these erosion mechanisms. Accordingly, soil erosion on cropland in the United States decreased by $41 \%$ between 1982 and 2010 (USDA, 2013). However, many studies do not account for soil loss from gully erosion processes, primarily because no systematic methodology exists to determine the spatial and temporal extent of gully erosion from the field to watershed scales (Bernard et al., 2010). A review of published data by Poesen et al. (2003) showed that as much as $94 \%$ of total soil loss can be contributed by gully erosion. Unfortunately, the complex formation and continued development of gully systems prohibit adequate assessment of soil losses and treatment practices by current prediction technology (Bernard et al., 2010).

Gully erosion is most commonly associated with the upstream migration of headcuts or knickpoints. Bennett et al. (2000) initiated an extensive research effort to improve understanding of physical characteristics of migrating headcuts, downstream sediment transport rates and gully bed adjustment. Their research provided an extensive database comprising: headcut migration rate, plunge pool geometry, channel slope, upstream flow discharge, downstream sediment yield, and bed morphology. Wells et al. $(2009 \mathrm{~b} ; 2010)$ extended this research to include the effects of tailwater elevation, pore-water pressure, and upstream sediment load. These datasets provide a platform to test new or future prediction technology.

Current USDA ephemeral-gully erosion models are based on either erosion-by-shear or erosion-by-headcut retreat formulations. Models simulating erosion-by-shear are generally based on components of the CREAMS (Chemicals, Runoff and Erosion from Agricultural Management Systems) model (USDA, 1980). CREAMS simulates ephemeral gully erosion through a procedure that takes into account detachment of soil through the shear force of flowing water, sediment transport capacity and changing channel dimensions. Models simulating erosion-by-headcut 
retreat, such as the Revised Ephemeral Gully Erosion Model (REGEM; Gordon et al., 2007) or its adaptation Tillage-Induced Ephemeral Gully Erosion Model (TIEGEM), which are used in the watershed-scale pollutant loading model Annualized AGricultural Non-Point Source (AnnAGNPS; Cronshey and Theurer, 1998), incorporate analytic formulations for plunge pool erosion and headcut retreat developed by Alonso et al. (2002) and extended by Gordon et al. (2007). Downstream sediment transport rates in both approaches are then computed by a balance between sediment inputs from hillslope and migrating headcuts, and sediment transport capacity (STC). CREAMS uses the Yalin (1963) STC equation, whereas REGEM and TIEGEM use the HUSLE STC equation (Theurer and Clarke, 1991).

Various researchers have tested STC equations for overland flow conditions. Alonso et al. (1981) found that the Yalin (1963) equation performed well in general. However, Guy et al. (1992) found that the Schoklitsch (1962) STC equation performs considerably better than the Yalin (1963) STC equation for steep, rough flow conditions. Hessel and Jetten (2007) examined the suitability of a number of transport equations for use in erosion modelling of the gully catchments of the Chinese Loess Plateau. They found that the Govers (1990) STC equation performed better than the Yalin (1963) STC equation because it has lower slope dependency. However, to date existing STC equations have not been tested specifically for gully flow conditions. This paper evaluates the performance of selected STC equations using a dataset obtained from flume experiments conducted at the USDA National Sedimentation Laboratory (e.g. Wells et al., 2009a; 2009b; 2010).

\section{APPROACH}

Six existing STC equations were evaluated using 22 runs (Table 1) included in the dataset compiled by Wells et al. (2009a; 2009b; 2010) from flume experiments of gully headcut migration. All experiments were conducted in a 5-m long and $0.165-\mathrm{m}$ wide, non-recirculating, tilting soil-hydraulic flume (Wells et al., 2010). This facility and procedures employed to apply rainfall and monitor runoff and erosion processes are described elsewhere (Wells et al., 2009a, 2009b). Procedures pertinent to the current discussion are briefly described below.

Bed slopes were $1 \%, 3 \%$, and $5 \%$. Flow discharge over the soil bed was controlled by two adjustable intake valves and monitored by a magnetic flow meter. The flow ranged from 25.3 to 74.0 L/min. Upstream (positioned 0.44-m upstream of the soil bed) and downstream (positioned 0.1-m upstream of the flume outlet) water surface elevations were monitored by acoustic transducers mounted above the flume (Wells et al., 2010). Water and sediment exiting the flume were captured in 0.5 -L glass bottles at 10 -s intervals for 3-min, and at 20-s intervals thereafter. Sediment samples were weighed, oven dried at $40.5^{\circ} \mathrm{C}$ for $24-\mathrm{h}$, then reweighed. Selected sediment samples were sieved to determine particle size distribution as percent mass of size for the following size fractions (all diameters are in $\mathrm{mm}$ ): coarser than $0.5,0.354,0.25,0.178,0.125$, $0.088,0.063$, and $<0.063$. Materials in the pan $(<0.063 \mathrm{~mm})$ were pipetted to determine size breaks for fine and coarse silt and clay. Bulk density samples were collected in aluminium rings pressed normal to the surface, excavated, cleaned, weighed, oven dried at $40.5^{\circ} \mathrm{C}$ for $24-\mathrm{h}$, then reweighed.

The soils used in this study include: Atwood sandy clay loam (fine-silty, mixed, thermic Typic Paleudalfs) with 59\% sand, $17 \%$ silt, and $24 \%$ clay; Dubbs silt loam (fine-silty, mixed, active, thermic Typic Hapludalfs) with $21 \%$ sand, $62 \%$ silt, and $17 \%$ clay; and Ruston fine sandy loam (fine-loamy, siliceous, semiactive, thermic Typic Paleudults) with 74\% sand, 5\% silt, and $21 \%$ clay (Wells et al., 2009a, 2009b, 2010). Grain size distributions of the three soils tested are provided in Figure 1.

Comparisons of measured and predicted sediment transport rates for six predictive equations were computed. Steady-uniform flow was assumed for hydraulic characteristics downstream of the migrating headcuts. Measured depth, depositional bed slope, and discharge values from six experimental setups were used to determine an average, single Manning $n$ roughness value of 0.0155 with a standard deviation of 0.0033 . The mean Manning $n$ value was used for all cases. A 
Table 1 Summary of experiments used to evaluate sediment transport capacity equations.

\begin{tabular}{lllllllll}
\hline Test & Soil series & $\begin{array}{l}\text { Initial bed } \\
\text { slope } \\
(\mathrm{cm} / \mathrm{cm})\end{array}$ & $\begin{array}{l}\text { Bulk } \\
\text { density } \\
\left(\mathrm{g} / \mathrm{cm}^{3}\right)\end{array}$ & $\begin{array}{l}\text { Discharge } \\
(\mathrm{L} / \mathrm{min})\end{array}$ & $\begin{array}{l}\text { Sediment } \\
\text { discharge } \\
(\mathrm{kg} / \mathrm{s})\end{array}$ & $\begin{array}{l}\text { Depositional } \\
\text { bed slope } \\
(\mathrm{cm} / \mathrm{cm})\end{array}$ & $\begin{array}{l}\text { Migration } \\
\text { rate } \\
(\mathrm{m} / \mathrm{s})\end{array}$ & $\begin{array}{l}\text { Max scour } \\
\text { depth } \\
(\mathrm{m})\end{array}$ \\
\hline 1 & Atwood & 0.01 & 1.434 & 68.20 & 0.0103 & 0.0049 & 0.00050 & 0.1077 \\
2 & Dubbs & 0.01 & 1.411 & 70.28 & 0.0046 & 0.0092 & 0.00017 & 0.0791 \\
3 & Ruston & 0.03 & 1.459 & 45.00 & 0.0223 & 0.0065 & 0.00149 & 0.0907 \\
4 & Atwood & 0.03 & 1.423 & 46.17 & 0.0060 & 0.0290 & 0.00026 & 0.1108 \\
5 & Atwood & 0.05 & 1.311 & 46.16 & 0.0302 & 0.0311 & 0.00224 & 0.0978 \\
6 & Atwood & 0.05 & 1.390 & 46.90 & 0.0044 & 0.0054 & 0.00015 & 0.1244 \\
7 & Ruston & 0.05 & 1.318 & 51.30 & 0.0318 & 0.0241 & 0.00218 & 0.1253 \\
8 & Ruston & 0.01 & 1.297 & 74.03 & 0.0270 & 0.0128 & 0.00255 & 0.0945 \\
9 & Ruston & 0.01 & 1.323 & 73.92 & 0.0150 & 0.0081 & 0.00115 & 0.1306 \\
10 & Atwood & 0.01 & 1.332 & 71.50 & 0.0210 & 0.0088 & 0.00192 & 0.1050 \\
11 & Atwood & 0.01 & 1.288 & 68.51 & 0.0236 & 0.0111 & 0.00251 & 0.0883 \\
12 & Atwood & 0.01 & 1.316 & 66.61 & 0.0372 & 0.0120 & 0.00420 & 0.0717 \\
13 & Atwood & 0.01 & 1.328 & 69.63 & 0.0399 & 0.0120 & 0.00367 & 0.0771 \\
14 & Atwood & 0.01 & 1.307 & 69.69 & 0.0261 & 0.0085 & 0.00186 & 0.0915 \\
15 & Atwood & 0.01 & 1.296 & 71.67 & 0.0220 & 0.0094 & 0.00174 & 0.0895 \\
16 & Atwood & 0.01 & 1.345 & 66.92 & 0.0344 & 0.0238 & 0.00236 & 0.0580 \\
17 & Atwood & 0.01 & 1.339 & 65.12 & 0.0281 & 0.0090 & 0.00235 & 0.0776 \\
18 & Atwood & 0.01 & 1.325 & 68.94 & 0.0319 & 0.0494 & 0.00173 & 0.0642 \\
19 & Atwood & 0.01 & 1.327 & 66.26 & 0.0322 & 0.0325 & 0.00214 & 0.0612 \\
20 & Atwood & 0.01 & 1.265 & 71.98 & 0.0154 & 0.0075 & 0.00229 & 0.0876 \\
21 & Dubbs & 0.05 & 1.316 & 57.15 & 0.0027 & 0.0018 & 0.00014 & 0.0887 \\
22 & Atwood & 0.03 & 1.508 & 25.29 & 0.0102 & 0.0084 & 0.00150 & 0.0907 \\
\hline & & & & & & & &
\end{tabular}

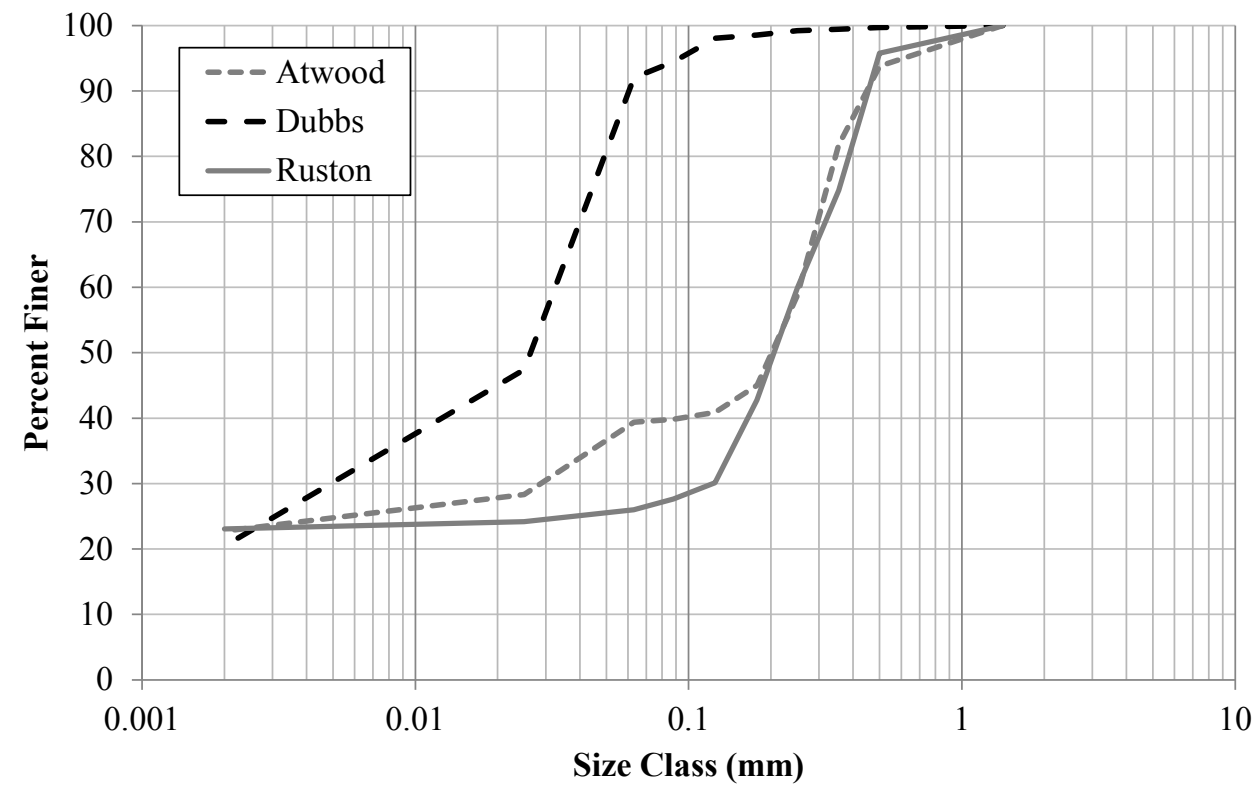

Fig. 1 Grain size distributions of soils tested.

single roughness value assumes that the roughness contribution due to bed composition was comparable between the three soils tested. The STC equations used for comparison are: Govers (1990), Laursen (1958), Schoklitsch (1962), Wu et al. (2000), Yalin (1963), and Yang (1973). Each of the sediment transport functions tested is briefly described as follows:

(a) Govers (1990) examined differing sediment transport theories, originally developed for alluvial channels, to predict transport in overland and rill flows. The theories tested included 
shear stress, effective stream power, and unit stream power. Govers (1990) collected data in a laboratory environment with slopes between 1 and 12 degrees and grain sizes varying from silt to coarse sand. The flow was not recirculated nor was any sediment added during testing. Relationships were developed for each of the theories and none were chosen as the overall ideal function. The relationship used herein is that described by Hessel and Jetten (2007), which was developed by Morgan et al. (1998) using data from Govers (1990). The relationship is based on unit stream power theory.

(b) Laursen (1958) developed an empirical relationship for sediment transport in alluvial channels. Particle sizes used for the relationship ranged from 0.04 to $4.08 \mathrm{~mm}$. The function accounts for sediment mixtures as it is applied by size class. Figures (as published in Laursen, 1958) used in the determination of sediment transport where digitized and regressed for application in programmatic comparisons.

(c) Schoklitsch (1962) is based on excess shear stress principles and was developed with data favouring alluvial channels. The range of valid size classes is between 0.305 and $7.02 \mathrm{~mm}$. The function can be applied to sediment mixtures by dividing into size classes.

(d) Wu et al. (2000) is based on critical shear stress principles while accounting for non-uniform sediment mixtures through a factor that is assumed to account for the probabilities associated with the hiding and exposure of particles. Field and laboratory data of conditions favouring alluvial channels with both uniform and non-uniform beds and grain sizes varying between 0.062 and $128 \mathrm{~mm}$ were used in development of the function.

(e) Yalin (1963) derived an expression for bed-load transport for steady-uniform flow with a uniform cohesionless bed. Yalin (1963) described the function as accounting for grain movement in saltation. Grain sizes used for validation ranged between 0.315 to $28.6 \mathrm{~mm}$. Materials with varying specific gravities were also used for validation.

(f) Yang (1973) first used unit stream power theory to predict sediment transport in alluvial channels with the use of 1225 sets of data, of which, 50 stemmed from field investigations. Average particle sizes ranged from 0.137 to $7.01 \mathrm{~mm}$. Yang (1984) extended the unit stream power theory to include gravel particles by providing two equations: one for sand and one for gravel. The equation for sand presented in Yang (1984) was used herein.

Grain size distributions used in conjunction with the predictive transport functions are based on five sediment size classes typical for cohesive soils at the point of detachment, as defined by Foster et al. (1985). The five size classes are: primary clay, primary silt, small aggregate, large aggregate, and primary sand. Distribution among the size classes is dependent on the primary particle distribution of the soil matrix. Primary particle size distribution data from the experimental runs were compared with Foster et al. (1985). Clays, silts and small aggregates were assumed to be washload and material trapped within the depositional bed was assumed to be sand and fine fraction materials contained in large aggregates.

\section{RESULTS AND DISCUSSION}

Results produced by the six transport functions varied greatly. The wide range may have been due to the use of a median grain diameter for some functions or the inclusion of silts and clays in functions that determine total transport by size class (i.e. Wu et al., 2000; Laursen, 1958). Since STC functions do not directly apply to the entrainment of cohesive materials without a proper mass balance, the transport of the smallest grains was calculated by considering the volume of material resulting from the measured migration rate of the headcut. Therefore, silts, clays, and small aggregates (all with fall velocity $<0.4 \mathrm{~mm} / \mathrm{s}$ ) were considered washload for all tests and added to STC function results for comparison to measured data. All STC functions were separately applied only to large aggregates and sands, based upon the normalized fractions of the two size classes (i.e. after removing clays, silts and small aggregates from the calculated grain size distribution using the equations of Foster et al., 1985). Note that the transport rates of clays, silts, and small aggregates were set equal to their detachment rate, which was directly computed from the observed headcut migration rate. 
Figure 2 compares measured and calculated total sediment discharge for the 22 tests. For each STC equation, a root mean square (rms) error was calculated using the $\log 10$ transformed data such that errors for large sediment discharges would not dominate the rms error (Table 2). Results were fairly consistent based upon the parameter used to represent the fluid forces acting on the sediment particles. Stream power functions, such as Yang (1973) and Govers (1990), compared well with the measured data. Excess shear stress approaches, such as Laursen (1958) and Wu et al. (2000), showed larger errors at higher shear stresses. These may be a result of assumptions made in the determination of the hydraulic characteristics. The Schoklitsch (1962) function was consistently lower than measured values; an observation also made by Hessel and Jetten (2007).

Table 2 Root mean square error and residual statistics (using $\log 10$ transformed data) of the evaluated STC functions.

\begin{tabular}{llcll}
\hline STC function & Rms error & Residual mean & Residual variance & Residual $\chi^{2}$ \\
\hline Govers (1990) & 0.2686 & 0.119 & 0.060 & 1.37 \\
Laursen (1958) & 0.7793 & 0.648 & 0.197 & 2.92 \\
Schoklitsch (1972) & 0.2436 & -0.140 & 0.042 & 0.247 \\
Wu et al. (2000) & 0.7337 & 0.585 & 0.205 & 1.46 \\
Yalin (1963) & 0.3889 & -0.328 & 0.046 & 0.012 \\
Yang (1973) & 0.2692 & -0.002 & 0.076 & 0.332 \\
\hline
\end{tabular}

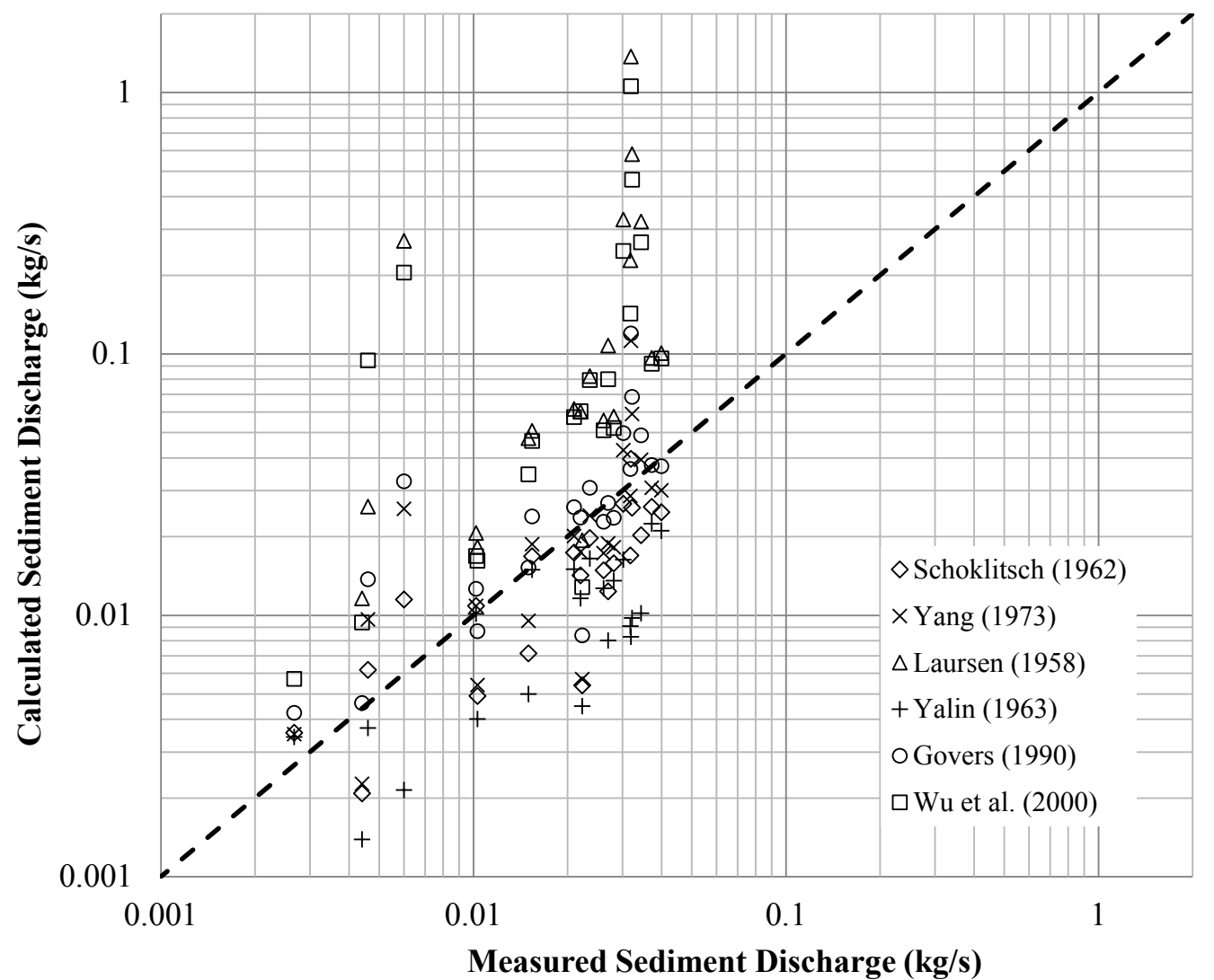

Fig. 2 Comparison of measured sediment discharge and that calculated by the evaluated STC functions.

\section{CONCLUSIONS}

The main conclusions of the research are:

(a) The transport of fine-grained size classes (clays, silts, and small aggregates) in ephemeral gullies downstream of migrating headcuts cannot be calculated by STC equations because their transport rates are determined by their rate of detachment under the conditions studied. 
(b) STC equations can be used to calculate the sediment transport of sands and large aggregates in ephemeral gullies downstream of migrating headcuts.

(c) STC equations based on unit stream power theory, such as Yang (1973) and Govers (1990), perform better than those based on excess shear stress theory, such as Laursen (1958) and Wu et al. (2000).

(d) Improved soil detachment relationships for ephemeral gullies are needed to predict the transport of clays, silts, and small aggregates.

\section{REFERENCES}

Alonso, C. V., Bennett, S. J. \& Stein, O. R. (2002) Predicting head cut erosion and migration in concentrated flows typical of upland areas. Water Resources Research 38(12), 3901-3915.

Alonso, C. V., Neibling, W. H. \& Foster, G. R. (1981) Estimating sediment transport capacity in watershed modeling. Transactions ASAE 24(5), 1211-1226.

Bennett, S. J., et al. (2000) Experiments on headcut growth and migration in concentrated flows typical of upland areas. Water Resources Research 36(7), 1911-1922.

Bernard, J., et al. (2010) Ephemeral gully erosion - A national resource concern. NSL Technical Research Report No. 69. USDA, Agricultural Research Service, National Sedimentation Laboratory, Oxford, MS.

Cronshey, R. G. \& Theurer, F. D. (1998) AnnAGNPS - non point pollutant loading model. In: Proceedings First Federal Interagency Hydrologic Modeling Conference, 1-9-1-16. Subcommittee on Hydrology of Interagency Advisory Committee on Water Data.

Foster, G. R., Young, R. A. \& Neibling, W. H. (1985) Sediment composition for nonpoint source pollution analysis. Transactions ASAE 28(1), 133-139.

Gordon, L. M., et al. (2007) Simulating ephemeral gully erosion in AnnAGNPS. Transactions ASABE 50(3), 857-866.

Govers, G. (1990) Empirical relationships for transport capacity of overland flow. In: Erosion, Transport, and Deposition Processes (ed. by D. E. Walling, A. Yair \& S. M. Berkowicz). IAHS Publication 189, 45-63.

Guy, B. T., Dickinson, W. T. \& Rudra, R. P. (1992) Evaluation of fluvial sediment transport equations for overland flow. Transactions ASAE 35(5), 545-555.

Hessel, R. \& Jetten, V. (2007) Suitability of transport equations in modelling soil erosion for a small Loess Plateau catchment. Engineering Geology 91(1), 56-71.

Laursen, E. M. (1958) The total sediment load of streams. Journal of the Hydraulics Division 8(HY1), 1530-11530-36.

Morgan, R. P. C., et al. (1998) The European Soil Erosion Model (EUROSEM): A dynamic approach for predicting sediment transport from fields and small catchments. Earth Surface Processes and Landforms 23(6), 527-544.

Poesen, J., et al. (2003) Gully erosion and environmental change: importance and research needs. Catena 50(2-4), 91-133.

Schoklitsch, A. (1962). Handbuch des Wasserbaus, Springer-Verlag, Vienna, Austria.

Theurer, F. D. \& Clarke, C. D. (1991) Wash load component for sediment yield modeling. In: Proceedings of the Fifth Federal Interagency Sedimentation Conference, 7-1-7-8. Subcommittee on Hydrology of Interagency Advisory Committee on Water Data.

US Department of Agriculture (USDA) (1980) CREAMS: A Field-Scale Model for Chemicals, Runoff, and Erosion from Agricultural Management Systems (ed. by W. G. Knisel), Conservation Research Report No. 26, 640 pp.

US Department of Agriculture (USDA) (2013) Summary report: 2010 National Resources Inventory. Natural Resources Conservation Service, Washington, DC, and Center for Survey Statistics and Methodology, Iowa State University, Ames, IA. Available from: http://www.nrcs.usda.gov/Internet/FSE_DOCUMENTS/stelprdb1 167354.pdf (23 March, 2014).

Wells, R. R., Alonso, C. V. \& Bennett, S. J. (2009a) Morphodynamics of headcut development and soil erosion in upland concentrated flows. Soil Science Society of America Journal 73(2), 521-530.

Wells, R. R., Bennett, S. J. \& Alonso, C. V. (2009b) Effect of soil texture, tailwater height, and pore-water pressure on the morphodynamics of migrating headcuts in upland concentrated flows. Earth Surface Processes and Landforms 34, 1867-1877.

Wells, R. R., Bennett, S. J. \& Alonso, C. V. (2010) Modulation of headcut soil erosion in rills due to upstream sediment loads. Water Resources Research 46, W12531, doi:10.1029/2010WR009433.

Wu, W., Wang, S. Y. \& Jia, Y. (2000) Nonuniform sediment transport in alluvial rivers. Journal of Hydraulic Research 38(6), $427-434$.

Yalin, M. S. (1963) An expression for bed-load transportation. Journal of the Hydraulics Division 89(HY3), 221-250.

Yang, C. T. (1973) Incipient motion and sediment transport. Journal of the Hydraulics Division 99(HY7), 919-934.

Yang, C. T. (1984) Unit stream power equation for gravel. Journal of Hydraulic Engineering 110(12), $1783-1797$. 